UDC 616.314.17:547.995]-092.9

https://doi.org/10.26641/2307-0404.2021.2.234382
O.V. Kopchak ${ }^{1}$,
L.F. Yakovenko ${ }^{2}$,
N.S. Marchenko ${ }^{1}$,
I.V. Kovach ${ }^{3}$,
E.M. Pavlenko ${ }^{1}$,
O.A. Nimenko ${ }^{2}$,
I.V. Kroupskaya ${ }^{2}$,
V.V. Filonenko ${ }^{2}$

\title{
LEVELS OF Hsp60 IN PERIODONTAL TISSUE OF RATS: INFLUENCE OF INJECTIONS OF HYALURONIC ACID
}

Private Higher Euducational Establisment «Kyiv medical University» ${ }^{1}$

Department of Therapeutic Dentistry

Boryspilska str., 2, Kyiv, 02099, Ukraine

e-mail:info@kmu.edu.ua

Institute of Molecular Biology and Genetics of NAS of Ukraine ${ }^{2}$

Department of Cell Signalling

Zabolotnogo str., 150, Kyiv, 03143, Ukraine

e-mail: inform@imbg.org.ua

Dnipro State Medical University ${ }^{3}$

Department of Pediatric Dentistry

V. Vernadsky str., 9, Dnipro, 49044, Ukraine

e-mail:dsma@dsma.dp.ua

ПВНЗ «Київський медичний університет» ${ }^{l}$

кафедра терапевтичної стоматології

(зав. - д. мед. н., дои. О.В. Копчак)

вул. Бориспільська, 2, Киї, 02099, Україна

Інститут молекулярної біології і генетики НАН України ${ }^{2}$

Відділ сигнальних систем клітини

(зав. - д. біол. н., проф. В.В. Філоненко)

вул. Ак. Заболотного, 150, Київ, 03143, Украӥна

Дніпровський державний медичний університет ${ }^{3}$

кафедра дитячої стоматологї

(зав. - д. мед. н., проф. І.В. Ковач)

вул. В. Вернадського, 9, Дніпро, Україна

Цитування: Медичні перспективи. 2021. Т. 26, № 2. С. 12-18

Cited: Medicni perspektivi. 2021;26(2):12-18

Key words: heat shock protein 60, periodontitis, hyaluronic acid

Ключові слова: білок теплового шоку 60, пародонтит, гіалуронова кислота

Ключевые слова: белок теплового шока 60, пародонтит, гиалуроновая кислота

Abstract. Levels of Hsp60 in periodontal tissue of rats: influence of injections of hyaluronic acid. Kopchak O.V., Yakovenko L.F., Marchenko N.S., Kovach I.V., Pavlenko E.M., Nimenko O.A., Kroupskaya I.V., Filonenko V.V. Heat shock protein 60 (Hsp60) is considered as one of the possible autoantigens involved in the pathogenesis of a number of chronic diseases including periodontal diseases. The application of hyaluronic acid or hyaluronan (HA) in the treatment of periodontitis has been evaluated in several clinical trials, however, the effect of hyaluronic acid on heat shock protein 60 level in periodontal soft tissues has not been studied. The aim of this work was to evaluate the effect of HA injections on levels of Hsp60 in periodontal tissue of the rats. Samples of periodontal tissue of mandibular incisors of adult male Wistar rats at 10-12 months of age were investigated. Rats were distributed into the control group and the periodontitis group. Visual manifestations of hyperemia of the gums around the incisors were the criterion for selecting animals into the periodontitis group. There were two subgroups in the control group: intact rats (I); intact rats after HA "hyaDENT BG" 1.0 MDa (BioScience GmbH, Germany) treatment (I+ "G-1.0"). There were four subgroups in the periodontitis group: rats with periodontitis (P); rats with periodontitis after HA "hyaDENT BG" $1.0 \mathrm{MDa}$ (BioScience GmbH, Germany) treatment (P+ "G-1.0”); rats with periodontitis after HA "SERTOBEC” 2.4 MDa (S.C. Rompharm Company S.R.L., Romania) treatment (P+ "S-2.4”); rats with periodontitis after HA "SERTOBEC Tendon" 2.4 MDa (S.C. Rompharm Company S.R.L., Romania) treatment (P+ "ST-2.4”). There were three animals in each subgroup. Rats were injected $0.05 \mathrm{ml} \mathrm{HA}$ in the area of alveolar processus of central incisors once a week, three times. Levels of Hsp60 
in total lysates of periodontal tissue were tested by Western blotting method before and after the treatment with HA (one month after the last injection). There was no significant difference between levels of Hsp60 in total lysates of periodontal tissue of intact rats and rats with periodontitis before treatment $(p>0.05)$. Rats with periodontitis showed decreased inflammation in the periodontal tissue after treatment with HA with different molecular weight. Intact rats and rats with periodontitis which were treated with HA "hyaDENT BG" 1.0 MDa showed reduced levels of Hsp60 in total lysates of periodontal tissue comparatively with levels of Hsp60 before treatment (by 15.4 and 10.7 times respectively, $p<0.001$ ). Rats with periodontitis which were treated with HA "SERTOBEC" 2.4 MDa or HA "SERTOBEC Tendon" 2.4 MDa also showed reduced levels of Hsp60 in total lysates of periodontal tissue comparatively with levels of Hsp60 before treatment (by 21.3 and 16.4 times respectively, $p<0.001)$. Rats with periodontitis showed the decrease in inflammation in periodontal tissue after treatment with HA with different molecular weight. Injections of HA has contributed to reduce levels of Hsp60 in periodontal tissue of intact rats and rats with periodontitis.

Реферат. Рівні Нsp60 у тканинах пародонта щурів: вплив ін'скцій гіалуронової кислоти. Копчак О.В., Яковенко Л.Ф., Марченко Н.С., Ковач І.В., Павленко Е.М., Німенко О.А., Крупська І.В., Філоненко В.В. Білок теплового шоку 60 (Hеat shock protein 60, Нsp60) вважається одним із можливих аутоантигенів, які залучено в патогенез хронічних захворювань, зокрема захворювань тканин пародонта. У науковій літературі представлено результати використання гіалуронової кислоти або гіалурону (НА) у лікуванні пародонтиту, проте вплив гіалурону на рівень білка теплового шоку 60 у м'яких тканинах пародонта не вивчено. Метою цієі роботи було дослідження впливу ін'єкиій НА на рівні Нsp60 у тканинах пародонта щурів. Досліджували зразки тканин пародонта нижньощелепних різиів дорослих щурів Wistar (вік 10-12 місяиів). Щурів було розподілено на дві групи: контрольна група та група пародонтиту. Візуальні прояви гіперемії ясен навколо різиів були критерієм відбору тварин до групи пародонтиту. У контрольній групі було дві підгрупи: інтактні щури (I); інтактні щури, яким вводили HA “hyaDENT BG” 1.0 MDa (BioScience GmbH, Germany), (I+"G-1.0”). У гpyni пародонтиту було чотири підгрупи: щури з пародонтитом (P); щури з пародонтитом, яким вводили НА “hyaDENT BG” 1.0 MDa (BioScience GmbH, Germany), (P+”G-1.0”); щури з пародонтитом, яким вводили НА “SERTOBEC” $2.4 \mathrm{MDa}$ (S.C. Rompharm Company S.R.L, Romania), (P+”S-2.4”); шури з пародонтитом, яким вводили HA “SERTOBEC Tendon” 2.4 MDa (S.C. Rompharm Company S.R.L., Romania), (P+”ST-2.4”). У кожній підгрупі було по три тварини. Щурам вводили по 0,05 мл НА у ділянку центральних різиів альвеолярного відростка один раз на тиждень, три рази. Рівні Нsр60 визначали в тотальних лізатах тканин пародонта методом Вестерн-блотингу до та після закінчення лікування (через один місяиь після останньої ін'єкиї). Не виявлено статистично достовірної різниці між рівнями Нsр60 у тотальних лізатах тканин пародонта інтактних щурів та щурів з парадонтитом до лікування (p>0,05). У тварин з пародонтитом установлено зменшення запалення тканин пародонта після лікування НА різної молекулярної маси. В інтактних щурів та щурів з парадонтитом через місящьь після останнього введення HA “hyаDENT BG” 1.0 MDa cпостерігалось зниження рівнів Hsp60 у тотальних лізатах тканин пародонта порівняно з рівнями Нsр60 до початку лікування (у 15,4 та 10,7 раза відповідно, p<0,001). У щурів з пародонтитом, яким вводили НА "SERTOBEC" $2.4 \mathrm{MDa}$ або HA “SERTOBEC Tendon” $2.4 \mathrm{Mda}$, також спостерігалось зниження рівнів Нsp60 у тотальних лізатах тканин пародонта порівняно з рівнями Нsp60 до початку лікування (y 21,3 та 16,4 раза відповідно, $p<0,001)$. У щурів з пародонтитом установлено зменшення запалення в тканинах пародонта після лікування НА різної молекулярної маси. Введення НА супроводжувалося зниженням рівнів Нsр60 у тканинах пародонта інтактних щурів та щурів з пародонтитом.

Heat shock protein 60 (Hsp60) is considered as one of the possible autoantigens involved in the pathogenesis of a number of chronic diseases including periodontal diseases [9]. Hsp60 belongs to a family of highly concerved stress proteins. The production of these proteins is evaluated under different stressors factors (cellular insult, environmental changes, temperature, infections, tumors etc.). Despite being highly homologous between eukaryotic and prokaryotic, Hsp60 is strongly immunogenic and immune responses to bacterial Hsp60 are speculated to initiate chronic inflammatory diseases in humans.

Periodontitis is defined as the chronic inflammation of periodontal supporting tissue caused by specific pathogenic microorganisms, resulting in the advanced destruction of the periodontal ligament and the alveolar bone and subsequently leading to the formation of a gingival recession and a periodontal pocket [19]. The precise mechanisms of tissue destruction, however, have not been fully elucidated.

Human Hsp60 is expressed abundantly in periodontitis lesions and can be an antigen-target for cross-reactive antibodies against bacterial Hsp60 [3, $8,9]$. Similar to bacterial lipopolysaccharide, Hsp60 is able to stimulate tumour necrosis factor (TNF)- $\alpha$ production from macrophages [3]. Thus, immune response to Hsp60 derived from either inflammatory tissue or bacteria was thought to play an important role in the development of autoimmune processes in periodontal tissue.

Hyaluronic acid or hyaluronan (HA) has been used in the treatment of periodontitis $[2,5,6,12,15,16]$. 
HA is an ubiquitous non-sulphated glycosaminoglycan with a high molecular weight. It is one of the components of the extracellular matrices of the connective tissue. HA has been identified in all periodontal tissues, being particularly prominent in the non-mineralized tissues such as gingiva and periodontal ligament and in only low quantities in mineralized tissues such as cementum and alveolar bone [14]. Fibroblasts, osteoblasts, and cementoblasts are capable of synthesizing HA in their cell membrane and secreting it to the exterior [13]. HA has anti-inflammatory, anti-edematous effect, promotes wound healing and also connective tissue angiogenesis [14]. There are no reports describing the effect of HA on levels of Hsp60 in periodontal tissue.

The aim of this work was to evaluate the effect of HA injections on levels of Hsp60 in the periodontal tissue of rats.

\section{MATERIALS AND METHODS OF RESEARCH}

Samples of periodontal tissue of mandibular incisors of adult male Wistar rats were investigated. Rats, 10-12 months of age, weighing 200-220 g were from the vivarium of the Bogomolets National Medical University. Animals were caged in a room with controlled temperature $\left(18^{\circ} \mathrm{C}\right)$ and humidity (60.5\%). The protocol of this study was approved by the Ethics Committee of the Bogomolets National Medical University. In experimental studies on animals adhered to the "European Convention for the protection of vertebrate animals used for experimental and other scientific purposes" (Strasbourg, 1986), "General ethical principles of animal experiments", approved by the First National Congress of Bioethics (Kyiv, 2001), Directive 2010/63/EU of European Parlament and Council on the protection of animals used for scientific purposes, Law of Ukraine No. 3447-IV dated February 21, 2006, order Ministry of Education and Science, Youth and Sports of Ukraine No. 249 dated March 1, 2012 [1, 7, 18, 20].

Rats were distributed into the control group and the periodontitis group. Visual manifestations of hyperemia of the gums around the incisors were the criterion for selecting animals into the periodontitis group. There were two subgroups in the control group: intact rats (I); intact rats after HA "hyaDENT BG” 1.0 MDa (BioScience GmbH, Germany) treatment (I+"G-1.0"). There were four subgroups in the periodontitis group: rats with periodontitis $(\mathrm{P})$; rats with periodontitis after HA "hyaDENT BG"1.0 $\mathrm{MDa}$ (BioScience $\mathrm{GmbH}$, Germany) treatment (P+"G-1.0"); rats with periodontitis after HA "SERTOBEC" 2.4 MDa (S.C. Rompharm Company S.R.L., Romania), treatment (P+"S-2.4"); rats with periodontitis after HA "SERTOBEC Tendon"
2.4 MDa (S.C. Rompharm Company S.R.L., Romania) treatment (P+"ST-2.4"). There were three animals in each subgroup. Rats were injected $0.05 \mathrm{ml} \mathrm{HA}$ in the area of alveolar ridge of central incisors once a week, three times. Levels of Hsp60 in total lysates of periodontal tissue were tested by Western blotting before and after the treatment with HA of different molecular weight (1 month after the last injection).

Samples of periodontal tissue were prepared by homogenization in ice-cold RIPA buffer $(20 \mathrm{mM}$ Tris- $\mathrm{HCl}, \mathrm{pH} 7.5 ; 0.15 \mathrm{M} \mathrm{NaCl} ; 1 \mathrm{mM}$ EDTA; $1 \%$ sodium deoxycholate; $0.1 \%$ SDS and $0.1 \%$ protease inhibitor cocktail). After 30 a minutes' extraction at $+4^{\circ} \mathrm{C}$, the samples were centrifuged at $10000 \mathrm{x} \mathrm{g}$ for $20 \mathrm{~min}$. at $+4^{\circ} \mathrm{C}$. The supernatants were collected and the protein concentration was determined by Nanodrop. Protein samples $(100 \mu \mathrm{g})$ were electrophoresed in $12 \%$ SDS polyacrylamide gel. The wet electrotransfer of proteins to the nitrocellulose membranes was held at $90 \mathrm{~V}$ for $40 \mathrm{~min}$. The membranes were blocked for $1 \mathrm{~h}$. at a room temperature with blocking buffer (5\% non-fat milk in PBS-tween buffer) and then probed with specific primary antibodies for $18 \mathrm{~h}$. at $+4^{\circ} \mathrm{C}$. After washing in PBS tween buffer (10 min $\times 3$ ) the membranes were incubated with peroxidase-conjugated secondary anti-rabbit (in case of Hsp60) or anti-mouse (in case of GAPDH) antibodies for $1 \mathrm{~h}$. at a room temperature. The polyclonal anti-GroEL antibody produced in rabbit and polyclonal anti-GAPDH antibody produced in mouse were developed in IMBG NAS of Ukraine. Immunologic crossreactivity of GroEL with Hsp60 was demonstrated previously [17]. The treatment of the membranes with secondary antibodies was followed by washing in PBS tween buffer (10 $\min \times 3)$ and chemiluminescence detection according to manufacturer's instructions by ChemiDoc. All samples of periodontal tissue were examined for levels of Hsp60 and GAPDH in six reproducible repetitions. The results of the first one are presented in the article.

Statistical analysis was performed using software environments STATISTICA 8.0 (StatSoft Inc. 2007, USA) and MS Excel 2010 (license number K9366093I 2016). Data were analyzed using Student's t-test, a $\mathrm{p}<0.001$ was considered significant.

\section{RESULTS AND DISCUSSION}

Rats with periodontitis showed decreased inflammation in the periodontal tissue after treatment with HA of different molecular weight. There were a decrease in gum hyperemia, an increase in soft tissue volume and an increase in vascularization in parodont of rats. 
Results of the investigation of the effect of HA injections on levels of Hsp60 in the total lysates of periodontal tissue are presented in the Figure. There was no significant difference between levels of Hsp60 in total lysates of periodontal tissue of intact rats and rats with periodontitis before treatment $(\mathrm{p}>0.05)$.

Intact rats and rats with periodontitis which were treated with HA "hyaDENT BG" 1.0 MDa showed reduced levels of Hsp60 in total lysates of perio- dontal tissue comparatively with levels of Hsp60 before treatment (by 15.4 and 10.7 times respectively, $\mathrm{p}<0.001)$. Rats with periodontitis which were treated with HA "SERTOBEC" $2.4 \mathrm{MDa}$ or HA "SERTOBEC Tendon" 2.4 MDa also showed reduced levels of Hsp60 in total lysates of periodontal tissue comparatively with levels of Hsp60 before treatment (by 21.3 and 16.4 times respectively, $\mathrm{p}<0.001$ ).

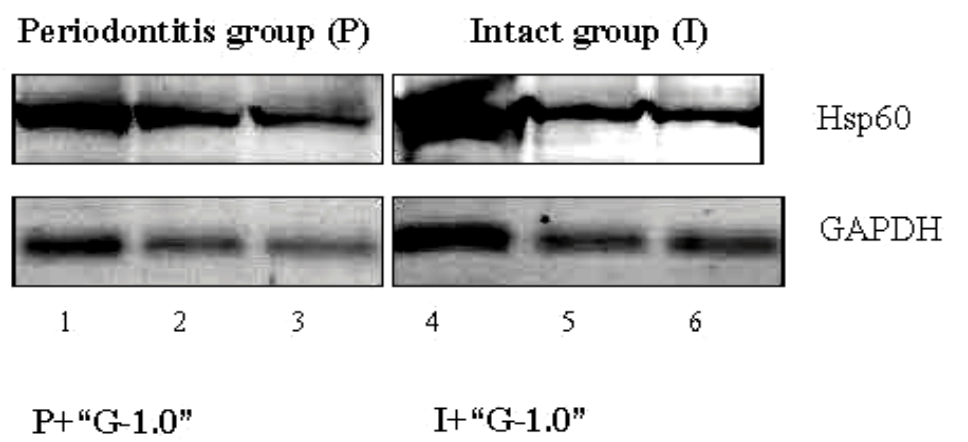

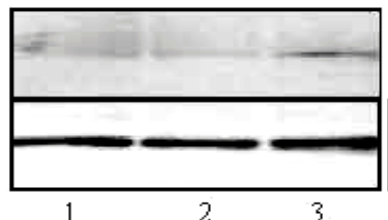

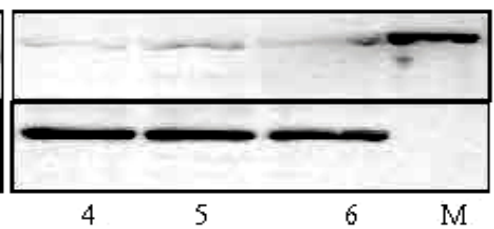

Hsp60

GAPDH

$\mathrm{P}+$ "S-2.4"

$\mathrm{P}+$ "ST-2.4"

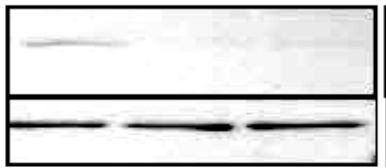

3

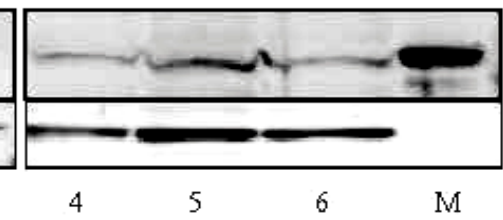

Hsp 60

$\mathrm{GAPDH}$

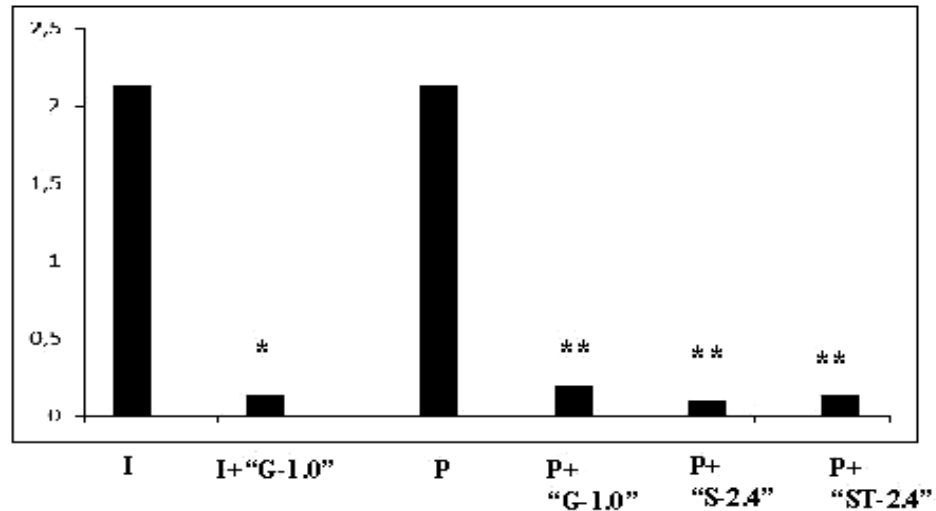

Notes: (A) Levels of Hsp60 in total lysates of periodontal tissue by Western blotting

(B) Quantitative densitometry analysis of levels of Hsp60 with GAPDH as an internal standard (total Hsp60/GAPDH), * - p $<0.001$ vs. the intact group, ${ }^{*}-\mathrm{p}<0.001$ vs. the periodontitis group, 1-6 - samples of periodontal tissue, $\mathrm{M}$ - a molecular-weight size marker.

Influence of injections of hyaluronic acid of different molecular weight on levels of $\mathrm{Hsp} 60$ in periodontal tissue of rats 
The integrity of periodontal tissues provides an effective barrier against microbial invasion and preventes the destruction of tissues by bacterial toxins and enzymes. This integrity is lost during chronic inflammation associated with periodontal diseases [11].

It was shown, the endogenous HA component results to be lacking within the epithelium and the gingival connective tissue with a consequent structural failure and loss of normal features of the gingiva. In patients with chronic periodontitis, there is a rapid loss of HA high molecular weight due to enzymatic digestive processes. Hyaluronidase, an enzyme released by microorganisms of bacterial plaque, plays an essential role in such mechanism [10].

Because of its properties and the non-immunogenicity of the highly purified form, HA has already found medical applications for many years. The application of HA in nonsurgical periodontal treatment has been evaluated in several clinical trials, but the current evidence is insufficient to support the routine clinical use $[2,5,6,12,15,16]$.

The aim of this pilot study was to investigate the influence of injection of HA on levels of Hsp60 in periodontal tissue. Significant difference between levels of Hsp60 in total lysates of the periodontal tissue of intact rats and rats with parodontitis before treatment was not demonstrated. The treatment with HA of different molecular weight has contributed to reduce levels of Hsp60 in total lisates of periodontal tissue of intact rats and rats with periodontitis.

Our clinical observations revealed a decrease in inflammation processes in parodontal tissue of rats with parodontitis after treatment with HA of different molecular weight.

Different mechanisms have been proposed to explain the influence of HA on the inflammatory process.

HA may regulate the inflammatory response, acting as an antioxidant by scavenging reactive oxygen species [6].
It was considered that HA produces a physical barrier against bacteria and their products in extracellular matrix. At physiological concentrations, HA molecules entangle and form a random network of chains. Such network interacts with other macromolecular components. HA excludes other macromolecules especially large ones that cannot find space in the network. It also retards the diffusion of other substances that can not penetrate the network [10].

HA has been shown to be bacteriostatic with respect to periodontal pathogens particularly to Actinobacillus actinomycetemcomitans, Prevotella oris, Staphylococcus aureus, and Propionibacterium acnes strains. Among the bacterial strains studied, HA was found to have no bactericidal effects [4].

HA may also prevent periodontal pathogen colonization by directly preventing microbial proliferation [6].

We were determined levels of Hsp60 in total lysates of periodontal tissue. Many different bacteria are present on the tissue surfaces and form the film. Protein that we determined in total lysates of periodontal tissue may be also bacterial Hsp60. Injections of HA of different molecular weight contributed to reduce the inflammation and possibly contributed to decline of the periodontal pathogens quantity. Thus, we observed decreased levels of Hsp60 in total lysates of periodontal tissue of rats.

\section{CONCLUSION.}

Rats with periodontitis showed decreased inflammation in periodontal tissue after treatment with HA of different molecular weight. Injections of HA contributed to reduce levels of Hsp60 in periodontal tissue of intact rats and rats with periodontitis.

Conflict of interests. The authors declare no conflict of interest.

\section{REFERENCES}

1. About the statement of the Order of carrying out by scientific institutions of experiments, experiments on animals: the order of the Ministry of Education and Science, Youth and Sports of Ukraine N 249 dated 01.03.2012 [Internet]. [cited $2018 \mathrm{Dec} 23$ ]. Available from: https://zakon.rada.gov.ua/go/z0416-12.

2. Koshal A, Patel P, Bolt R, Dawett B, Galgut PN. A comparison in postoperative healing of sites receiving non-surgical debridement augmented with and without a single application of hyaluronan $0.8 \%$ gel. J Prev Dent. 2007;2:34-7.

3. Yamazaki K, Ohsawa Y, Tabeta K, Ito H, Ueki K, Oda T, Yoshie H, and Seymour GJ. Accumulation of Hu- man Heat Shock Protein 60-Reactive T Cells in the Gingival Tissues of Periodontitis Patients. Inf Immun. 2002; 70:2492-501.

doi: https://doi.org/10.1128/IAI.70.5.2492-2501.2002

4. Pirnazar P, Wolinsky L, Nachnani S, Haake S, Pilloni A, Bernard GW. Bacteriostatic effects of Hyaluronic Acid. Journal of Periodontology. 1999;70(4):370-4. doi: https://doi.org/10.1902/jop.1999.70.4.370

5. Bogaerde VL. Treatment of infrabony periodontal defects with esterified hyaluronic acid: Clinical report of 19 consecutive lesions. Int J Periodontics Restorative Dent. 2009;29:315-23. 
6. Dahiya P, Kamal R. Hyaluronic Acid: a boon in periodontal therapy. N Am J Med Sci. 2013;5(5):309-15. doi: https://doi.org/10.4103/1947-2714.112473

7. Directive 2010/63/EU of the European Parliament and of the Council of 22 September 2010 on the protection of animals used for scientific purposes (Text with EEA relevance) [Internet]. [cited 2018 Dec 23]. Available from: https://eurlex.europa.eu/LexUriServ/LexUriServ.do?uri=OJ:L:2010:276:0033:0079:en:PDF

8. Yamazaki K, Ueki-Maruayama K, Honda T, Nakajima T, Seymour GJ. Effect of periodontal treatment on the serum antibody levels to heat shock proteins. Clin Exp Immunol. 2004;135(3):478-82.

doi: https://doi.org/10.1111/j.1365-2249.2003.02375.x

9. Tabeta K, Yamazaki K, Hotokezaka H, Yoshie H, Hara K. Elevated humoral immune response to heat shock protein 60 (hsp60) family in periodontitis patients. Clin Exp Immunol. 2000;120(2):285-93.

doi: https://doi.org/10.1046/j.1365-2249.2000.01216.x

10. Pilloni A, Annibali S, Dominici F, Di Paolo C, Papa M, Cassini MA, Polimeni A. Evaluation of the efficacy of an hyaluronic acid-based biogel on periodontal clinical parameters. A randomized-controlled clinical pilot study. Ann Stomatol (Roma). 2011;2(3-4):3-9.

11. Gontiya G, Galgali SR. Effect of hyaluronan on periodontitis: A clinical and histological study. J Indian Soc Periodontol. 2012;16(2):184-92.

doi: https://doi.org/10.4103/0972-124X.99260

12. Rajan P, Baramappa R, Rao NM, Pavaluri AK, Indeevar P, Rahaman SM. Hyaluronic acid as an adjunct to scaling and root planing in chronic periodontitis. A randomized clinical trail. J Clin Diagn Res. 2014;8:ZC114. doi: https://doi.org/10.7860/JCDR/2014/8848.5237

13. Litwiniuk M, Krejner A, Speyrer MS, Gauto AR, Grzela T. Hyaluronic acid in inflammation and tissue regeneration. Wounds. 2016;28:78-88.
14. Casale M, Moffa A, Vella P, Sabatino L, Capuano F, Salvinelli B, et al. Hyaluronic acid: Perspectives in dentistry. A systematic review. Int $\mathrm{J}$ Immunopathol Pharmacol. 2016;29:572-82.

doi: https://doi.org/10.1177/0394632016652906

15. Johannsen A, Tellefsen M, Wikesjö U, Johannsen G. Local delivery of hyaluronan as an adjunct to scaling and root planing in the treatment of chronic periodontitis. J Periodontol. 2009;80:1493-7.

doi: https://doi.org/10.1902/jop.2009.090128

16. Polepalle T, Srinivas M, Swamy N, Aluru S, Chakrapani S, Chowdary BA. Local delivery of hyaluronan $0.8 \%$ as an adjunct to scaling and root planing in the treatment of chronic periodontitis: A clinical and microbiological study. J Indian Soc Periodontol. 2015;19:37-42. doi: https://doi.org/10.4103/0972-124X.145807

17. Kapustian LN, Kyyamova RG, Gryshkova VS, Terentiev AG, Sidorik LL. Obtaining recombinant chaperon CroEL and its immunological cross-reactivity with Hsp60. Biopolym. Cell. 2006;22 (2):117-120. doi: https://doi.org/10.7124/bc.000724

18. On the protection of animals from cruel treatment: the law of Ukraine N 3447-IV. from 21.02.2006 [Internet]. [cited $2018 \mathrm{Dec} 23]$ Available from: https://zakon.rada.gov.ua/go/3447-15.

19. Zhao Y-J, Li Q, Cheng B-X, Zhang M, and Chen Y-J. Psychological Stress Delays Periodontitis Healing in Rats: The Involvement of Basic Fibroblast Growth Factor. Mediators of Inflammation. 2012;13. doi: https://doi.org/10.1155/2012/732902

20. Kozhemyakin UM, Khromov OS, Filonenko MO, Saifetdinova GA. Scientific and practical recommendations for keeping laboratory animals and working with them. Kyiv; 2002. p. 155.

\section{СПИСОК ЛІТЕРАТУРИ}

1. About the statement of the Order of carrying out by scientific institutions of experiments, experiments on animals: the order of the Ministry of Education and Science, Youth and Sports of Ukraine N 249 dated 01.03.2012 [Internet]. [cited 2018 Dec 23]. Available from: https://zakon.rada.gov.ua/go/z0416-12.

2. A comparison in postoperative healing of sites receiving non-surgical debridement augmented with and without a single application of hyaluronan $0.8 \%$ gel / A. Koshal et al. J Prev Dent. 2007. Vol. 2. P. 34-37.

3. Accumulation of Human Heat Shock Protein 60Reactive T Cells in the Gingival Tissues of Periodontitis Patients / K. Yamazaki et al. Inf Immun. 2002. Vol. 70. P. 2492-2501

DOI: https://doi.org/10.1128/IAI.70.5.2492-2501.2002

4. Bacteriostatic effects of Hyaluronic Acid / P. Pirnazar et al. Journal of Periodontology. 1999. Vol. 70, No. 4. P. 370-374.

DOI: https://doi.org/10.1902/jop.1999.70.4.370
5. Bogaerde V. L. Treatment of infrabony periodontal defects with esterified hyaluronic acid: Clinical report of 19 consecutive lesions. Int $J$ Periodontics Restorative Dent. 2009. Vol. 29. P. 315-323.

6. Dahiya P., Kamal R. Hyaluronic Acid: a boon in periodontal therapy. $N$ Am J Med Sci. 2013. Vol.5, No. 5. P. 309-315.

DOI: https://doi.org/10.4103/1947-2714.112473

7. Directive $2010 / 63 / \mathrm{EU}$ of the European Parliament and of the Council of 22 September 2010 on the protection of animals used for scientific purposes (Text with EEA relevance) [Internet]. [cited 2018 Dec 23]. Available from: https://eurlex.europa.eu/LexUriServ/LexUriServ.do?uri=OJ:L:2010:276:0033:0079:en:PDF

8. Effect of periodontal treatment on the serum antibody levels to heat shock proteins / K. Yamazaki et al. Clin Exp Immunol. 2004. Vol. 135, No. 3. P. 478-482. DOI: https://doi.org/10.1111/j.1365-2249.2003.02375.x

9. Elevated humoral immune response to heat shock protein 60 (hsp60) family in periodontitis patients / 
K. Tabeta et al. Clin Exp Immunol. 2000. Vol. 120, No. 2.P. 285-293.

DOI: https://doi.org/10.1046/j.1365-2249.2000.01216.x

10. Evaluation of the efficacy of an hyaluronic acidbased biogel on periodontal clinical parameters. A randomized-controlled clinical pilot study / A. Pilloni et al. Ann Stomatol (Roma). 2011. Vol. 2, No. 3-4. P. 3-9.

11. Gontiya G., Galgali S. R. Effect of hyaluronan on periodontitis: A clinical and histological study. $J$ Indian Soc Periodontol. 2012. Vol. 16, No. 2. P. 184-192. DOI: https://doi.org/10.4103/0972-124X.99260

12. Hyaluronic acid as an adjunct to scaling and root planing in chronic periodontitis. A randomized clinical trail / P. Rajan et al. J Clin Diagn Res. 2014. Vol. 8. P. ZC11-14.

DOI: https://doi.org/10.7860/JCDR/2014/8848.5237

13. Hyaluronic acid in inflammation and tissue regeneration / M. Litwiniuk et al. Wounds. 2016. Vol. 28. P. 78-88.

14. Hyaluronic acid: Perspectives in dentistry. A systematic review / M. Casale et al. Int. J. Immunopathol Pharmacol. 2016. Vol. 29. P. 572-582.

DOI: https://doi.org/10.1177/0394632016652906

15. Johannsen A., Tellefsen M., Wikesjö U., Johannsen $\mathrm{G}$. Local delivery of hyaluronan as an adjunct to scaling and root planing in the treatment of chronic periodontitis. J Periodontol. 2009. Vol. 80. P. 1493-1497. DOI: https://doi.org/10.1902/jop.2009.090128

16. Local delivery of hyaluronan $0.8 \%$ as an adjunct to scaling and root planing in the treatment of chronic periodontitis: A clinical and microbiological study / T. Polepalle et al. J Indian Soc Periodontol. 2015. Vol. 19. P. 37-42.

DOI: https://doi.org/10.4103/0972-124X.145807

17. Obtaining recombinant chaperon CroEL and its immunological cross-reactivity with Hsp60 / L. N. Kapustian et al. Biopolym. Cell. 2006. Vol. 22, No. 2. P. 117-120. DOI: https://doi.org/10.7124/bc.000724

18. On the protection of animals from cruel treatment: the law of Ukraine № 3447-IV. from 21.02.2006 [Internet]. [cited 2018 Dec 23]. Available from: https://zakon.rada.gov.ua/go/3447-15.

19. Psychological Stress Delays Periodontitis Healing in Rats: The Involvement of Basic Fibroblast Growth Factor / Y-J. Zhao et al. Mediators of Inflammation. 2012. P. 13. DOI: https://doi.org/10.1155/2012/732902

20. Scientific and practical recommendations for keeping laboratory animals and working with them / U. M. Kozhemyakin et al. Kyiv, 2002. 155 p.

The article was received 2020.06.04 